\title{
sciendo
}

\author{
Current Issues in Pharmacy and Medical Sciences
}

Formerly ANNALES UNIVERSITATIS MARIAE CURIE-SKIODOWSKA, SECTIO DDD, PHARMACIA

journal homepage: http://www.curipms.umlub.pl/

\section{Evaluation of antibacterial and antifungal properties of selected mouthwashes: in vitro studies}

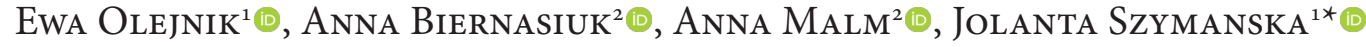

${ }^{1}$ Chair of Comprehensive Dentistry, Department of Comprehensive of Pediatric and Adult Dentistry, Medical University of Lublin, Poland

${ }^{2}$ Chair and Department of Pharmaceutical Microbiology, Medical University of Lublin, Poland

\section{ARTICLE INFO \\ Received 06 June 2021 \\ Accepted 16 September 2021}

\section{Keywords:}

mouthwashes,

dental plaque,

prevention,

antimicrobial efficacy,

sodium fluoride,

cetylpyridinium chloride.

\begin{abstract}
Introduction. Mouthwashes should include antimicrobial compounds to inhibit microorganism multiplication, thus the formation and development of dental plaque. Aim. The aim of the study was to evaluate the antibacterial and antifungal effectiveness of mouthwashes depending on their active ingredients.

Material and methods. In the study, the effect of antibacterial and antifungal properties of mouthwashes on reference bacterial and yeast-like fungi strains was examined. The first type of the assessed mouthwashes contained only sodium fluoride or sodium fluoride and amine fluoride as active ingredients, while the second type contained sodium fluoride and cetylpyridinium chloride.

In the study, a well diffusion method was used to test microorganisms constituting natural or pathogenic microflora of oral mucosa. The used reference microorganisms came from the ATCC: L. acidophilus ATCC 4356, Lactobacillus rhamnosus ATCC 53103, S. mutans ATCC 25175, and Candida yeasts: C. albicans ATCC 2091, C. albicans ATCC 10231, Candida parapsilosis ATCC 22019, Candida glabrata ATCC 90030, Candida krusei ATCC 14243.

Results. The mouthwashes containing sodium fluoride and cetylpyridinium chloride showed an inhibitory effect against a greater number of reference strains used in the study than did mouthwashes that contained only sodium fluoride (or sodium fluoride and amine fluoride) as active ingredients. Against the four reference strains of Candida genus, the mouthwashes with an inorganic and organic fluoride compound showed no or minimum inhibitory effect or were much less effective than the mouthwashes that also contained cetylpyridinium chloride.

Conclusion. Mouthwashes containing multiple ingredients with different antimicrobial mechanisms show synergistic action against the bacterial and fungal microflora responsible for the accumulation of dental plaque.
\end{abstract}

\section{INTRODUCTION}

The presence of dental plaque, which is in fact, bacterial biofilm, is a source of dental caries, gingivitis, periodontitis and mucositis. The spots where dental plaque mainly accumulates are teeth surfaces along the gum line, in the form of supragingival and subgingival plaque, as well as anatomical teeth furrows and cavities, and carious lesions. Other spots that should also be mentioned are crowded teeth areas, inappropriately made fillings, prosthetic restorations and orthodontic braces - fixed and removable [1].

Supragingival plaque is dominated by Gram-positive bacteria, including Streptococcus sanguinis, Streptococcus

\footnotetext{
* Corresponding author

e-mail: jolanta.szymanska@umlub.pl
}

mutans, Streptococcus mitis, Streptococcus salivarius and lactic acid bacteria, and it is a cause of dental caries. Subgingival plaque is responsible for gingivitis and periodontitis, and mainly involves anaerobic Gram-negative bacteria, such as Aggregatibacter (Actinobacillus) actinomycetemcomitans, Tannerella forsythia, Campylobacter spp., Capnocytophoga spp., Eikenella corrodens, Fusobacterium nucleatum, Porphyromonas gingivalis, Prevotella intermedia, and oral spirochetes including Treponema denticola [2].

Scientific evidence shows the possibility of participation of Candida yeast-like fungi in a cariogenic process, and biofilms formed by S. mutans and Candida albicans indicate increased cariogenic potential compared to biofilms of one species [3]. 
The hidden cariogenic potential of Candida species is connected with their virulence characteristics, such as acidogenecity and acidoduricity, ability to form abundant biofilms, to ferment and absorb sugars from food, as well as to create collagenolytic proteinases. Data suggest that Candida yeast-like fungi can play a key role as a secondary factor preserving cariogenic process, especially in dentine caries [4].

The principal method of preventing the formation of bacterial biofilm in the oral cavity is hygiene based on regular mechanical removal of bacterial plaque with a toothbrush, toothpaste and dental flosses. This process is complemented by using mouthwashes to reach areas inaccessible to toothbrushes. Mouthwashes should contain antimicrobial compounds, thereby inhibiting microorganisms multiplication, thus formation and development of dental plaque. Routine mouth rinsing after teeth brushing should be performed once-twice a day.

Mouthwashes contain agents with antibacterial properties, most frequently chlorhexidine, triclosan, and cetylpyridinium chloride (CPC) [5].

Most toothpastes, mouthwashes, dental flosses and chewing gums contain fluorine compounds, and most frequently they are sodium fluoride, stannous fluoride, sodium monofluorophosphate, and aminofluorides. The principal activity of fluorine is that of anticariogenic [6], aiming at decreasing enamel demineralization and favoring remineralization of damaged surfaces of hard dental tissues [7]. Moreover, fluorine decreases formation of bacterial plaque and reduces the quantity of cariogenic bacteria (S. mutans, L. acidophilus). It influences the metabolism of bacterial cells, modifying carbohydrate metabolism by inhibition of enolase - the fluoride ion, through connecting with the magnesium ion enolase molecule, inhibits its activity [8]. Mouthwashes evaluated in the own studies contained sodium fluoride in various concentrations.

Cetylpyridinium chloride (CPC) shows bactericidal activity against Gram-positive bacteria and activity (albeit, weaker) against Gram-negative. It also reveals fungicidal activity (C. albicans). It is not active against acid-resistant mycobacteria and viruses. Due to its antibacterial properties, it is widely used as an ingredient in mouthwashes [9]. It works by absorption to negatively charged teeth surfaces and bacterial plaque, and by decreasing surface tension of the bacterial cell membrane, what consequently results in its rupture and the destruction of the bacterial cell. What is more, it influences bacteria metabolism and significantly reduces adhesion of microorganisms to teeth surfaces [10]. By way of its properties, CPC is well and quickly absorbed by teeth surfaces - this considerably decreases adhesion of bacteria to hard dental tissues, reducing amount of bacterial plaque. Apart from fluorine compounds, it is the most frequently used mouthwash ingredient [7].

\section{AIM}

The aim of the study was to evaluate the antibacterial and antifungal effectiveness of mouthwashes depending on their active ingredients.

\section{MATERIALS AND METHODS}

The influence of six mouthwashes on the reference bacterial and yeast-like fungi strains was evaluated. The impact of the following mouthwashes was assessed: Colgate Plax Cool Mint (Colgate-Palmolive ${ }^{\circledR}$ ), Listerine Professional (Listerine ${ }^{\circledR}$ ), Oral B Pro-Expert (Procter \& Gamble ${ }^{\circledR}$ ), Mint Perfekt Sensitiv (Ziaja ${ }^{\circledR}$ ), Elmex (Gaba International AG $^{\circledR}$ ), and Smile 3D Protection "Multi Care" (Smile 3D Protection $\left.^{\circledR}\right)$. The listed products are the most popular among the patients who were under preventive and therapeutic care of the authors' department. All the selected mouthwashes are widely available in pharmacies, drug stores, and shops.

The mouthwashes containing sodium fluoride and amine fluoride (olaflur) include: Mint Perfekt Sensitiv by Ziaja (250 ppm F), Elmex (250 ppm F), and Listerine Professional (220 ppm F).

Sodium fluoride and cetylpyridinium chloride are ingredients of the following mouthwashes: Smile 3D Protection "Multi Care" (500 ppm F), Colgate Plax Cool Mint (225 ppm F) and Oral B Pro-Expert Clinic Line (98 ppm F) (Tab. 1).

Table 1. Ingredients of the evaluated mouthwashes

\begin{tabular}{|c|c|}
\hline Mouthwash & Ingredients \\
\hline $\begin{array}{l}\text { Colgate Plax Cool Mint } \\
\text { (Colgate-Palmolive }{ }^{\circledR} \text { ) }\end{array}$ & $\begin{array}{l}\text { water, glycerin, sorbitol, cetylpyridinium } \\
\text { chloride, sodium fluoride } 0.05 \% \text { ( } 225 \mathrm{ppm} \mathrm{F} \text { ), } \\
\text { menthol, propylene glycol, poloxamer 407, } \\
\text { potassium sorbate, saccharin, patent blue } \\
(\mathrm{CI} 42051)\end{array}$ \\
\hline $\begin{array}{l}\text { Listerine Professional } \\
\text { (Listerine }{ }^{\circledR} \text { ) }\end{array}$ & $\begin{array}{l}\text { dipotassium oxalate } 1.4 \% \text {, water, } \\
\text { propylene glycol, phosphoric acid, aroma, } \\
\text { poloxamer 407, sodium benzoate, sodium } \\
\text { methyl cocoyl taurate, sodium lauryl sulfate, } \\
\text { sodium fluoride ( } 220 \mathrm{ppm} \text { F), sucralose, sodium } \\
\text { saccharin }\end{array}$ \\
\hline $\begin{array}{l}\text { Oral B Pro-Expert } \\
\text { (Procter \& Gamble }{ }^{\circledR} \text { ) }\end{array}$ & $\begin{array}{l}\text { water, glycerin, aroma, polysorbate } 20, \\
\text { cetylpyridinium chloride }(0.05 \%) \text {, sodium } \\
\text { fluoride }(98 \mathrm{ppm} \mathrm{F}) \text {, saccharin, methylparaben, } \\
\text { sodium benzoate, propylparaben, patent blue } \\
(\mathrm{CI} 42051)\end{array}$ \\
\hline $\begin{array}{l}\text { Mint Perfekt Sensitiv } \\
\left(\text { Ziaja }{ }^{\circledR}\right)\end{array}$ & $\begin{array}{l}\text { water, hydrogenated castor oil, betaine, olaflur, } \\
\text { sodium fluoride }(0.025 \%) \text {, potassium nitrate, } \\
\text { sodium saccharin, sodium benzoate, aroma, } \\
\text { dipentane, eugenol, citric acid, propylene glycol, } \\
\text { fuchsia (CI } 17200)\end{array}$ \\
\hline $\begin{array}{l}\text { Elmex } \\
\left.\text { (Gaba International } A G{ }^{\circledR}\right)\end{array}$ & $\begin{array}{l}\text { water, hydrogenated castor oil, aroma, sodium } \\
\text { fluoride }(0.025 \%) \text {, olaflur, potassium acesulfame, } \\
\text { polyaminopropyl biguanide, hydrochloric acid }\end{array}$ \\
\hline $\begin{array}{l}\text { Smile 3D Protection } \\
\text { Multi Care } \\
\left(\text { Smile 3D Protection }{ }^{\circledR}\right)\end{array}$ & $\begin{array}{l}\text { water, glycerin, hydrogenated castor oil, sodium } \\
\text { fluoride ( } 500 \mathrm{ppm} \text { F), cetylpyridinium chloride, } \\
\text { aroma, saccharin, sodium benzoate, citric acid, } \\
\text { patent blue (CI 42051), tetrasodium EDTA, } \\
\text { polysorbate 20, sodium citrate, dipentane, } \\
\text { quinolone yellow (CI 47005) }\end{array}$ \\
\hline
\end{tabular}

The following kinds of media were used in the study:

- to grow Lactobacillus spp. and to evaluate antiseptic activity of the studied mouthwashes against reference bacteria strains - Rogosa Agar or MRS Agar;

- to grow $S$. mutans and to evaluate antiseptic activity of the studied mouthwashes against reference bacteria strains - Mitis Salivarius Agar with 5\% of sheep blood;

- to grow Candida spp. and to evaluate antiseptic activity of the studied mouthwashes against reference yeasts strains - Sabouraud agar.

In the study of antibacterial and antifungal activities of six selected mouthwashes, the well diffusion method was used in reference to microorganisms constituting natural or pathogenic microflora of oral mucosa. The used reference microorganisms came from the ATCC (American Type Culture Collection). It included the following bacteria: L. acidophilus ATCC 4356, Lactobacillus rhamnosus ATCC 53103, 
S. mutans ATCC 25175, and Candida yeasts: C. albicans ATCC 2091, C. albicans ATCC 10231, Candida parapsilosis ATCC 22019, Candida glabrata ATCC 90030, Candida krusei ATCC 14243.

Initially, microorganisms were multiplied (1-5 days, temperature $35-37^{\circ} \mathrm{C}$, in the case of lactic acid - additionally in anaerobic conditions) on the appropriate propagation media. Next, suspensions were prepared out of them in the sterile physiological fluid $(0.85 \% \mathrm{NaCl})$ with a strictly defined density of $0.5 \mathrm{McF}$ arland. The following stage was seeding with sterile swab in three different directions on the proper selective media. When the whole surface of plate was covered with microorganisms suspension, wells were cut in the medium with a sterile $10 \mathrm{~mm}$ diameter punch. After that, $100 \mu \mathrm{l}$ of each of the studied mouthwashes was distributed to the wells and all was pre-incubated for 1 hour in order to diffuse fluid to the medium. Thereafter, plates were incubated in appropriate conditions, i.e., Candida spp. $-35-37^{\circ} \mathrm{C}, 2$ days, aerobic conditions; S. mutans $-35-37^{\circ} \mathrm{C}$, 3 days, aerobic conditions; L. acidophilus $-35-37^{\circ} \mathrm{C}, 3-5$ days, anaerobic conditions. After the above-mentioned time, the plates were taken out and inhibition zone diameters around the wells with studied mouthwashes were observed. Diameters were measured in mm and compared. The most representative results were used to evaluate the antibacterial and antifungal activity of the tested mouthwashes.

\section{RESULTS}

As it is shown in Table 2, growth in microorganisms around the wells with the studied antiseptic rinses was to various degrees inhibited. Each of the selected mouthwashes had a number allocated, as follows:

- no. 1 - Colgate Plax Cool Mint (Colgate-Palmolive ${ }^{\circledR}$ ),

- no. 2 - Listerine Professional (Listerine ${ }^{\circledR}$ ),

- no. 3 - Oral B Pro-Expert (Procter \& Gamble ${ }^{\circledR}$ ),

- no. 4 - Mint Perfekt Sensitiv (Ziaja ${ }^{\circledR}$ ),

- no. 5 - Elmex (Gaba International $\mathrm{AG}^{\circledR}$ ),

- no. 6 - Smile 3D Protection "Multi Care" (Smile 3D Protection ${ }^{\circledR}$ ).

Inhibition zones varied from 0 to $30 \mathrm{~mm}$ in the case of bacteria and from 0 to $24 \mathrm{~mm}$ in the case of yeasts. The studied mouthwashes showed antimicrobial activity, both antibacterial and antifungal, except for mouthwashes no. 4 (Mint Perfekt Sensitiv) and no. 2 (Listerine Professional), the spectrum of which was only limited to bacteria. Growth in $L$. acidophilus ATCC 4356, L. rhamnosus ATCC 53103 and S. mutans ATCC 25175 was inhibited by mouthwash no. 4 (Mint Perfekt Sensitiv). The product also inhibited Candida yeasts ( $C$. albicans ATCC 10231) to the minimum level. In turn, mouthwash no. 2 (Listerine Professional) had inhibitory effect only on growth of L. acidophilus ATCC 4356 and L. rhamnosus ATCC 53103, and it did not exhibit inhibiting influence on S. mutans bacteria and Candida fungi strains yeasts. The following mouthwashes: no. 6 (Smile 3D Protection "Multi Care"), no. 3 (Oral B Pro-Expert), no. 1 (Colgate Plax Cool Mint) and no. 5 (Elmex) showed inhibiting influence on all the selected microorganisms.

The greatest inhibiting impact on growth of L. acidophilus ATCC 4356 was shown by mouthwash no. 6 (Smile 3D Protection "Multi Care"), followed by no. 4 (Mint Perfekt Sensitiv). Similar activity was indicated by mouthwashes no. 3 (Oral B Pro-Expert), no. 1 (Colgate Plax Cool Mint) and no. 5 (Elmex). Product no. 2 (Listerine Professional) was the least effective in inhibiting L. acidophilus ATCC 4356 growth.

The greatest inhibiting impact on growth of L. rhamnosus ATCC 53103 was evidenced by mouthwash no. 4 (Mint Perfekt Sensitiv), followed by no. 6 (Smile 3D Protection "Multi Care"). To a lesser degree, growth in those bacteria was inhibited by mouthwashes no. 1 (Colgate Plax Cool Mint), no. 5 (Elmex) and no. 3 (Oral B Pro-Expert), while the least effective was mouthwash no. 2 (Listerine Professional).

The greatest inhibiting impact on growth of $S$. mutans ATCC 25175 was demonstrated by product no. 1 (Colgate Plax Cool Mint). To a lesser degree, inhibiting activity against $S$. mutans was shown by mouthwashes no. 3 (Oral B Pro-Expert), no. 6 (Smile 3D Protection "Multi Care"), no. 4 (Mint Perfekt Sensitiv) and no. 5 (Elmex). As mentioned before, mouth rinse no. 2 (Listerine Professional) did not reveal antibacterial activity against $S$. mutans at all. The mouthwashes no. 6 (Smile 3D Protection "Multi Care"), no. 3 (Oral B Pro-Expert) and no. 1 (Colgate Plax Cool Mint) exhibited similar inhibiting influence on growth of all the studied yeas-like fungi strains. Product no. 5 (Elmex) indicated weaker activity against Candida yeasts. Mouthwash no. 4 (Mint Perfekt Sensitiv) showed negligible impact on inhibition of $C$. albicans ATCC 10231 growth and did not inhibit growth of remaining studied Candida yeasts. Product no. 2 (Listerine Professional) showed inhibiting property against none of the studied yeasts.

\section{DISCUSSION}

In vitro studies of susceptibility of reference bacteria and fungi strains to activity of antimicrobial compounds allow

Table 2. Antimicrobial activity of mouthwashes against selected reference bacteria and

\begin{tabular}{|c|c|c|c|c|c|c|}
\hline \multirow{3}{*}{ Microorganisms } & \multicolumn{6}{|c|}{$\begin{array}{c}\text { Inhibition zone of microorganisms growth around a well } \\
\text { with mouthwash (mm) }\end{array}$} \\
\hline & $\begin{array}{c}\text { Colgate Plax } \\
\text { Cool Mint } \\
\text { (Colgate- } \\
\text { Palmolive }{ }^{\circledR} \text { ) }\end{array}$ & \begin{tabular}{|c|} 
Listerine \\
Professional \\
(Listerine $^{\circledR}$ )
\end{tabular} & $\begin{array}{c}\text { Oral B Pro- } \\
\text { Expert } \\
\text { (Procter \& } \\
\left.\text { Gamble }^{\circledR}\right)\end{array}$ & $\begin{array}{c}\text { Mint Perfekt } \\
\text { Sensitiv } \\
\left(\text { Ziaja }^{\circledR}\right)\end{array}$ & $\begin{array}{c}\text { Elmex } \\
\text { (Gaba } \\
\text { International } \\
\mathrm{AG}^{\circledR} \text { ) }\end{array}$ & \begin{tabular}{|c|} 
Smile 3D \\
Protection \\
"Multi Care" \\
(Smile 3D \\
Protection $\left.{ }^{\circledR}\right)$ \\
\end{tabular} \\
\hline & 1 & 2 & 3 & 4 & 5 & 6 \\
\hline $\begin{array}{l}\text { Lactobacillus acidophilus } \\
\text { ATCC } 4356\end{array}$ & $20-21$ & $16-17$ & $20-22$ & $22-23$ & $21-22$ & $25-26$ \\
\hline $\begin{array}{l}\text { Lactobacillus rhamnosus } \\
\text { ATCC } 53103\end{array}$ & $20-21$ & $12-13$ & $19-20$ & $28-30$ & $19-21$ & $24-25$ \\
\hline $\begin{array}{l}\text { Streptococcus mutans } \\
\text { ATCC } 25175\end{array}$ & $23-24$ & 0 & $20-21$ & $15-17$ & $15-16$ & $19-20$ \\
\hline $\begin{array}{l}\text { Candida albicans } \\
\text { ATCC } 2091\end{array}$ & $19-20$ & 0 & $18-23$ & 0 & $15-16$ & $20-22$ \\
\hline $\begin{array}{l}\text { Candida albicans } \\
\text { ATCC } 10231\end{array}$ & $19-20$ & 0 & $17-19$ & $7-9$ & $13-14$ & $20-21$ \\
\hline $\begin{array}{l}\text { Candida parapsilosis } \\
\text { ATCC } 22019\end{array}$ & $20-21$ & 0 & $19-20$ & 0 & $14-17$ & $20-21$ \\
\hline $\begin{array}{l}\text { Candida glabrata } \\
\text { ATCC } 90030\end{array}$ & $21-22$ & 0 & $20-21$ & 0 & $17-18$ & $20-21$ \\
\hline $\begin{array}{l}\text { Candida krusei } \\
\text { ATCC } 14243\end{array}$ & $23-24$ & 0 & $20-21$ & 0 & $14-15$ & $21-22$ \\
\hline
\end{tabular}


for evaluation of influence of active substances on selected microorganisms. As far as mouthwashes are concerned, it is vital to establish optimal lists of ingredients, which, due to active substance content, would most effectively induce a reduction of the bacteria and fungi constituting dental plaque.

In our work, we demonstrated the significantly greater antibacterial properties against $S$. mutans of the mouthwashes containing sodium fluoride and cetylpyridinium chloride, compared to the mouthwashes containing only fluoride compounds. In the evaluation of various antibacterial substances efficacy against $S$. mutans grown on ready-made enamel slabs, Savas et al. also observed that a mouthwash containing both compounds was more effective in reducing the quantity of $S$. mutans colonies [11].

Evidence of the antibacterial synergistic activity of sodium fluoride and cetylpyridinium chloride against $S$. mutans strains was indicated in the $100 \%$ reduction of bacteria in oral bacterial biofilm after the use of mouthwash containing both ingredients. In contrast, after the use of mouthwash involving only $\mathrm{NaF}$, the number of $S$. mutans present in dental plaque was reduced by only $16.82 \%$ [12].

Similarly to own studies, in Brazilian studies, no positive influence of Listerine $\AA(\mathrm{NaF})$ mouthwash on the reduction of $S$. mutans was found. However, a similar impact of Colgate Plax $₫$ and Oral $\mathrm{B} ~(\mathrm{NaF}$ and $\mathrm{CPC})$ mouthwashes on decrease in the quantity of $S$. mutans was stated. This confirms the effectiveness of synergistic activity of both ingredients against $S$. mutans bacteria [13].

The mere presence of fluorine as an active ingredient in a mouthwash does not significantly influence the reduction of $S$. mutans strains, when compared with a mouthwash containing chlorhexidine and fluorine. This was revealed in evaluating influence of mouthwashes with various ingredients on recently extracted maxillary premolars. In this case, the synergistic antibacterial activity of chlorhexidine and fluorine against $S$. mutans was also confirmed [14].

Greater antibacterial activity of a mouthwash containing sodium fluoride and cetylpyridinium chloride (Oral B $($ ) against $S$. mutans, as compared to a mouthwash involving sodium fluoride (Listerine ${ }^{\circledR}$ ) was found out in saliva after the use of the mentioned mouthwashes in the study by Cardoso et al. Therein, the inhibiting influence of both products against $S$. mutans was demonstrated. In this study, the antibacterial activity of Oral B $®$ mouthwash was higher, and a reduction of $S$. mutans quantity from $6.75 \mathrm{CFU} / \mathrm{ml}$ to $6.00 \mathrm{CFU} / \mathrm{ml}$ in saliva was observed after the use of this product. After the use of Listerine ${ }^{\circledR}$, however, insignificant reduction of $S$. mutans quantity from $6.81 \mathrm{CFU} / \mathrm{ml}$ to 6.79 $\mathrm{CFU} / \mathrm{ml}$ was noticed [15]. In our studies, the significant inhibiting impact of Oral B $®$ mouthwash on S. mutans ATCC 25175 was confirmed, as well as lack of this impact in the case of Listerine ${ }^{\circledR}$ mouthwash. Similarly, the inhibiting influence of Oral B $₫$ mouthwash on reference Streptococcus bacteria strains was confirmed in previous studies [16].

Evans et al. compared the antibacterial influence of mouthwashes containing individual active ingredients - sodium fluoride in concentration of $0.05 \%$ (Colgate Neutrafluor $220 \AA$ ) and cetylpyridinium chloride in the concentration of $0.05 \%$ (Cepacol ${ }^{\circledR}$ ) on reference $S$. mutans and L. acidophilus strains.
They saw that inhibition zone was, respectively, equal to $7.5 \mathrm{~mm}$ for $S$. mutans and $12 \mathrm{~mm}$ for L. acidophilus in the case of mouthwashes with sodium fluoride, and, respectively, $8.6 \mathrm{~mm}$ and $11.1 \mathrm{~mm}$ - with cetylpyridinium chloride. Each of the active ingredients separately showed similar antibacterial properties, however, both ingredients together (present in Colgate Plax Cool Mint, Oral B Pro-Expert, Smile 3D Protection "Multi Care") showed significantly weaker influence on reference streptococci strains than in the case of own studies - which was confirmed by almost twice bigger inhibition zones [17].

In another study, a comparison of the antibacterial influence of Colgate Plax $\AA$ and Listerine $\AA$ mouthwashes on reference $S$. mutans and L. acidophilus strains, both of which play significant roles in the etiology of dental caries, showed the impact of both mouthwashes on the reduction of streptococci colonies. After the use of Colgate Plax ${ }^{\circledR}$ mouthwash, a $S$. mutans inhibition zone with diameter of $22 \pm 2 \mathrm{~mm}$ was observed, while after the use of Listerine $\AA$, this was $23 \pm 1.73 \mathrm{~mm}$. Furthermore, the inhibition zone of lactobacilli growth after the use of Colgate Plax ${ }^{\circledR}$ was equal to $20 \pm 2 \mathrm{~mm}$, while after the use of Listerine $\AA$ the figure was $11 \pm 1 \mathrm{~mm}[18]$. In our work, the inhibition zone of $S$. mutans growth by Colgate Plax Cool Mint ${ }^{\circledR}$ mouthwash amounted to 23-24 mm, whereas Listerine ${ }^{\circledR}$ mouthwash did not show any inhibiting activity against $S$. mutans. Moreover, weaker activity against $L$. acidophilus and L. rhamnosus was shown by Colgate Plax Cool Mint $\AA$ mouthwash - in both cases, the inhibition zone was equal to $20-21 \mathrm{~mm}$, whilst Listerine ${ }^{\circledR}$ mouthwash showed greater antibacterial properties against lactic acid bacteria - from $12-13$ to $16-17 \mathrm{~mm}$, than was in the case of the above mentioned results of other authors.

Interesting results were obtained by Ximenes et al., who studied the influence of active ingredients of mouthwashes on reference S. mutans, L. acidophilus, and E. faecalis strains. They saw greater antibacterial impact of a mouthwash containing $\mathrm{NaF}$ and chlorhexidine on L. acidophilus than a mouthwash involving only sodium fluoride. What is more, greater reduction of $S$. mutans quantity was stated with mere sodium fluoride than with the use of a mouthwash including chlorhexidine and sodium fluoride [19].

Our studies indicated the similar influence of Colgate Plax Cool Mint ${ }^{\circledR}$, Smile 3D Protection $\AA$, and Oral B Pro-Expert $\AA$ mouthwashes, therefore those containing cetylpyridinium chloride and sodium fluoride, on inhibition of reference C. albicans growth. However, no inhibiting activity was found in Listerine $\AA$ and Mint Perfekt Sensitiv ${ }^{\circledR}$, i.e., mouthwashes with sodium fluoride and amine fluoride as active ingredients. Similar results were obtained by the Polish researchers [20] who evaluated an influence of, among others, Colgate Plax $₫$, Oral B Pro-

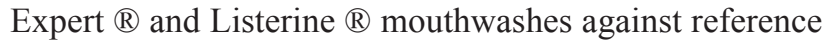
Candida yeasts strains, and revealed that Colgate Plax ${ }^{\circledR}$ mouth rinse inhibited growth of Candida yeasts in a zone with a diameter of $19.14 \mathrm{~mm}$. A similar inhibition zone was achieved in our study, wherein it was equal to $20 \mathrm{~mm}$. An approximately similar impact of Oral $B \mathbb{B}$ mouthwash on reference $C$. albicans strains was also indicated in other 
studies, in which the inhibition zone of Candida yeasts after the use of this mouth rinse amounted to $23 \mathrm{~mm}$ [21].

As with our own study, Brazilian researchers did not find a positive impact of Listerine ${ }^{\circledR}$ mouthwash on reduction of the quantity of Candida yeasts colonies, whereas Oral B $\AA$ and Colgate Plax ${ }^{\circledR}$ mouthwashes demonstrated a reduction of C. albicans strains [13].

Paulone et al. also achieved a reduction of the number of reference $C$. albicans strains after the use of a mouthwash containing both fluorine and chlorhexidine. The studies confirmed that both compounds showed synergistic activity. This enabled the achievement of better effects in reducing of the number of $C$. albicans yeasts [22]. In our study conducted on the reference fungi strains, the greatest inhibiting influence on the growth of selected Candida strains was confirmed by mouthwashes containing sodium fluoride and cetylpyridinium chloride, while mouthwashes including sodium fluoride as an active ingredient did not inhibit the growth or inhibited it in a very limited range. Among the latter, only Elmex ${ }^{\circledR}$ mouthwash showed inhibition zone of growth of selected Candida strains (from 13-14 mm to $17-18 \mathrm{~mm}$ ).

Our work and research by other authors confirm that mouthwashes containing multiple ingredients with different antimicrobial mechanisms have a broader spectrum of activity against the bacterial and fungal microflora responsible for the accumulation of dental plague than do mouthwashes with single active ingredients [11-15, 20-22]. This knowledge is extremely important and useful for dentists in their everyday clinical practice, and provides a guide for their recommendations for choice of appropriate mouthwashes for individual patients, both for prophylactic and therapeutic purposes, according to the clinical condition and composition of the patient's oral microbiome.

\section{CONCLUSIONS}

The varied antimicrobial activity of mouthwashes was confirmed. Mouthwashes containing sodium fluoride and cetylpyridinium chloride showed an inhibitory effect against a greater number of reference strains than did mouthwashes which contained only sodium fluoride or sodium fluoride and aminofluoride as active ingredients. From the clinical perspective, it is necessary to choose mouthwashes containing different active ingredients, according to the prophylactic and therapeutic needs of patients.

\section{ORCID iDs}

Ewa Olejnik (1)https://orcid.org/0000-0002-2851-843X Anna Biernasiuk (Dhttps://orcid.org/0000-0002-2844-9876 Anna Malm (Dhttps://orcid.org/0000-0003-1503-7634 Jolanta Szymańska (Dhttps://orcid.org/0000-0002-9917-2907

\section{REFERNCES}

1. Chałas R, Wójcik-Chęcińska I, Woźniak MJ, Grzonka J, Święszkowski W, Kurzydłowski KJ. Płytka bakteryjna jako biofilm - zagrożenia w jamie ustnej oraz sposoby zapobiegania. Postepy Hig Med Dosw. 2015;69:1140-8.

2. He XS, Shi WY. Oral microbiology: past, present and future. Int J Oral Sci. 2009;1:47-58.

3. Falsetta ML, Klein MI, Colonne PM, Scott-Anne K, Gregoire S, Pai C-H, et al. Symbiotic relationship between Streptococcus mutans and Candida albicans synergizes virulence of plaque biofilms in vivo. Infect Immun. 2014;82:1968-81.

4. Pereira DC, Seneviratne J, Koga-Ito CY, Samaranayake LP. Is the oral fungal pathogen Candida albicans a cariogen? Oral Dis. 2018;24: 518-26. doi: 10.1111/odi.12691. Epub 2017 Jun 13.

5. Ciancio SG. Mouthwashes: Rationale for use. Am J Dent. 2015;28 Spec. No. A:4A-8A.

6. Rugg-Gunn A. Dental caries: strategies to control this preventable disease. Acta Medica Academica. 2013;42:117-30.

7. Farah CS, McIntosh L, McCullough MJ. Mouthwashes. Aust Prescr. 2009;32:162-4.

8. Lussi A, Hellwig E, Klimek J. Fluorides - made of action and recommendations for use. Schweiz Monatsschr Zahnmed. 2012;122: 1030-42.

9. Haq MW, Batool M, Ahsan SH, Sharma G. Efficacy of antiplaque mouthwashes: a five-day clinical trial. Gen Dent. 2011;59(3):e110-115.

10. Latimer J, Munday JL, Buzza KM, Forbes S, Sreenivasan PK, McBain AJ. Antibacterial and anti-biofilm activity of mouthrinses containing cetylpyridinium chloride and sodium fluoride. BMC Microbiology. 2015; 15. https://www.ncbi.nlm.nih.gov/pubmed/ 26293609.

11. Savas S, Kucukyilmaz E, Clik EC, Ates M. Effects of different antibacterial agents on enamel in a biofilm caries model. J Oral Sci. 2015;57:367-72.

12. Yang SJ, Han SH, Lee AR, Jun JH, Son MW, Oh SH, et al. Evaluation of antimicrobial effects of commercial mouthwashes utilized in South Korea. BMB Rep. 2015;48:42-7.

13. Oliveira JR, Belato KK, Oliveira FE, Cardoso Jorge AO, Camargo SEA, Oliveira LD. Mouthwashes: an in vitro study of their action on microbial biofilms and cytotoxicity to gingival fibroblast. Gen Dent. 2018;66:28-34.

14. Jazaeri M, Pakdel F, Rezael-Soufi L, Abdolsamadi H. Cariostatic effects of green tea in comparison with common anticariogenic agents: an in vitro study. J Dent Res Dent Clin Dent Prosp. 2015; 9:44-8.

15. Cardoso TR, Cavalho AS, Beletti ME, Napimoga MH, Thedei G. Metabolic activity of Streptococcus mutans biofilms after treatment with different mouthwash formulations. Braz J Oral Sci. 2011;10:74-8.

16. Poureslami HR, Barkam F, Poureslami P, Salari Z, Salari S. Comparison of antibacterial effect of fluoride and chlorhexidine on two cariogenic bacteria: an in vitro study. J Dent Biomat. 2014;1:27-31.

17. Evans AS, Leishma J, Walsh LJ, Seow WK. Inhibitory effects of antiseptic mouthrinses on Streptococcus mutans, Streptococcus sanguinis and Lactobacillus acidophilus. Austr Dent J. 2015;60:247-54.

18. Akinyele BJ, Oladejo BO, Akinyemi AI, Ezem LO. Comparative study of the antibacterial effect of mouth washes and Vernonia amygdalina (del.) on some tooth decay causing bacteria. Br Microbiol Res J. 2014; 4:749-58.

19. Ximenes M, Cardoso M, Astorga F, Arnold R, Pimenta LA, Viera R. Antimicrobial activity of ozone and NaF-chlorhexidine on early childhood caries. Braz Oral Res. 2017;31:1-10.

20. Moroz J, Kurnatowski P. The in vitro activity of selected mouthrinses on standard strains of fungi. Ann Parasitology. 2017;63:331-9.

21. Talebi S, Sabokbar A, Riazipour M, Saffari M. Comparison of the in vitro effect of chemical and herbal mouthwashes on Candida albicans. Jundishapur J Microbiol. 2014;7:1-8.

22. Paulone S, Malavasi G, Arizzoni A, Orsi CF, Peppoloni A. Candida albicans survival, growth and biofilm formation are differently affected by mouthwashes: an in vitro study. New Microbiol. 2017;40:45-52. 